\title{
Cell turnover in tissues of the long-lived ocean quahog Arctica islandica and the short-lived scallop Aequipecten opercularis
}

\author{
Julia Strahl • Doris Abele
}

Received: 17 November 2009/ Accepted: 5 February 2010

(C) Springer-Verlag 2010

\begin{abstract}
Cell proliferation and apoptosis were investigated in tissues of two bivalve species, Arctica islandica from the German Bight (age of bivalves: 33-98 years) and Iceland (7-148 years) and Aequipecten opercularis from the English Channel (2-4 years). High proliferation rates (10\% nuclei dividing) and apoptosis in tissues of A. opercularis were in line with high-energy throughput and reduced investment into antioxidant defence mechanisms in the scallop. In contrast, cell turnover was slow $(<1 \%$ nuclei dividing) in A. islandica and similar in mantle, gill and adductor muscle between young and old individuals. In the heart, cell turnover rates decreased with age, which indicates less-efficient removal of damaged cells in ageing A. islandica. Cell turnover rates, mass specific respiration and antioxidant enzyme activities were similar in German Bight and Iceland ocean quahog. Variable maximum life expectancies in geographically separated A. islandica populations are determined by extrinsic factors rather than by fundamental physiological differences.
\end{abstract}

\section{Introduction}

Bivalve maximum life span potentials (MLSP) vary between just a few and several hundreds of years, and a large variety of different life history models can be found

Communicated by J. P. Grassle.

J. Strahl · D. Abele $(\bowtie)$

Alfred-Wegener Institute for Polar and Marine Research, Am Handelshafen 12, 27570 Bremerhaven, Germany

e-mail: Doris.Abele@awi.de

J. Strahl

University of Bremen, Leobener Str., 28359 Bremen, Germany among molluscs. Currently, bivalves are discussed as new models in ageing research that add to the understanding of the mechanistic basis of longevity with a focus on physiology and gene expression of long- and short-lived bivalve species (Abele et al. 2009; Bodnar 2009; Philipp and Abele 2009). The ocean quahog Arctica islandica with reported individual ages of $>350$ years in an Icelandic population (Schöne et al. 2005; Wanamaker et al. 2008) and the queen scallop Aequipecten opercularis with a MLSP of only 810 years, represent not only extremes in life spans but also life styles. Arctica islandica is rather inactive, burrowing beneath the sediment surface but remaining in contact with the overlying sea water through short siphons for oxygen uptake and feeding. At regular intervals, the clams burrow deeper into the sediment exposing themselves to hypoxia for periods of 1-7 days and inducing metabolic rate depression (MRD) (Taylor 1976). When experiencing prolonged hypoxia of $>24 \mathrm{~h}$, the ocean quahog reduces its metabolism to $10 \%$, and after several days of experimental anoxia to as low as $1 \%$ of their aerobic rates (Oeschger and Storey 1993). Arctica islandica occurs on the continental shelves on both sides of the North Atlantic in Europe and North America (Nicol 1951; Thompson et al. 1980; Jones 1980; Murawski et al. 1982; Dahlgren et al. 2000), spanning an overall temperature range from 0 to $16^{\circ} \mathrm{C}$ (Mann 1982). In contrast, A. opercularis is an actively swimming epibenthic scallop with a wide geographical distribution on the European continental shelf from Northern Norway to Gibraltar and within the Mediterranean (Waller 1991), tolerating water temperatures of $6-24^{\circ} \mathrm{C}$ (Ansell et al. 1991). The scallops swim through jet propulsion reaching speeds up to $30 \mathrm{~cm} \mathrm{~s}^{-1}$ (Moore and Trueman 1971).

Since the pioneer work of Pearl (1928) and Harman (1956), proposing the 'Free Radical—Rate of Living theory', which predicts a negative correlation between mass 
specific respiration (MSR) and MLSP of a species, studies of ageing focus on the link between mitochondrial production of reactive oxygen species (ROS) and MSR. Applying this theory to the molluscs, a variety of physiological parameters such as growth, metabolism, antioxidant defence and accumulation of oxidative damage products have been studied in different tissues of several bivalves and squids in an age-dependent manner (Philipp et al. 2005a, b, 2006; Strahl et al. 2007; Abele et al. 2008; Zielinski and Pörtner 2000). The long-lived Icelandic A. islandica has stable antioxidant capacities in mantle and gill over an age range of 30-200 years (Abele et al. 2008) and the fluorescent age pigment lipofuscin, an oxidative stress and ageing marker, accumulates in several tissues as they age (Strahl et al. 2007). The abundance of lipofuscin granules differs between highest densities in gills, less in mantle and hardly detectable accumulations in the adductor muscle of very old clams. The protein carbonyl concentration resulting from protein oxidation remains low in A. islandica up to 200 years compared to shorter-lived bivalves (Strahl et al. 2007). In contrast, mitochondrial volume density, as well as antioxidant protection decrease significantly in mantle tissue of ageing A. opercularis, within only a couple of years. Lipofuscin content in mantle tissue increases with age, and protein carbonyls are twice as concentrated as in 200-year-old A. islandica (Philipp et al. 2006; Strahl et al. 2007). These results indicate that the energy-saving life style of $A$. islandica reduces oxygen radical damage accumulation and maintains high antioxidant capacities into extremely old age. In contrast, high-energy throughput and the epibenthic lifestyle of A. opercularis are correlated with a short life expectancy, due to an elevated risk of predation compared to burrowing bivalves, and a restricted investment in cellular protection and mitochondrial maintenance in mature specimens.

In the present work, we investigated tissue maintenance in terms of cell proliferation and apoptosis in mantle, gill, adductor muscle, and heart of both bivalve model species A. islandica and A. opercularis. Cell division and programmed cell death are essential processes in multicellular organisms, which eliminate and replace damaged, infected and senescent cells. Apoptosis is a highly regulated energyconsuming process in which intracellular compounds are degraded and disposed of in an orderly manner, without the induction of inflammation. Caspases, a family of proteases involved in the apoptotic program, have recently been described in bivalves (Sokolova et al. 2004; Sokolova 2009). Both, proliferation and apoptosis of fatally damaged cells may dilute and eliminate waste products such as lipofuscin and protein carbonyls, as well as damaged mitochondria in bivalve tissues, which thereby preserve function over an individual's lifetime. Young (7-13 years), middle-aged (27-33 years) and old (93-148 years)
Icelandic A. islandica were studied to test for age-dependent capacity differences in proliferation and apoptosis in a long-lived organism. We included a second $A$. islandica population from the German Bight, to test for possible intra-specific variability, and compared cell turnover rates as well as antioxidant enzyme activities and mass specific respiration rates between individuals from both populations. Ocean quahog from the German Bight have shorter life expectancy than the Iceland population and reported problems with new recruitment, which is possibly induced by environmental conditions and results in missing age cohorts $<30$ and $>100$ years (Begum et al. 2009).

\section{Materials and methods}

Bivalve collection and maintenance

Arctica islandica were collected at Helgoland "Tiefe Rinne" in the German Bight $\left(54^{\circ} 09.05^{\prime} \mathrm{N}, 07^{\circ} 52.06^{\prime} \mathrm{E}\right)$ at 40-45 m water depth, using a hydraulic dredge in May 2008. Surface water temperature on the sampling date was $12^{\circ} \mathrm{C}$. In August 2008, A. islandica were collected northeast of Iceland $\left(66^{\circ} 01.44^{\prime} \mathrm{N}, 14^{\circ} 50.91^{\prime} \mathrm{W}\right)$ at $8-15 \mathrm{~m}$ water depth and water surface temperatures of $9^{\circ} \mathrm{C}$. Clams were transported in a cooled container to the Sandgerdi Marine Centre, University of Iceland, where they were kept for 2 weeks at constant temperature $\left(9^{\circ} \mathrm{C}\right)$ and salinity $(34$ PSU) in 400-1 tanks. Aequipecten opercularis were dredged in the English Channel $\left(48^{\circ} 43.07^{\prime} \mathrm{N}, 03^{\circ} 59.02^{\prime} \mathrm{E}\right)$ in August 2008 at about $60-\mathrm{m}$ water depth and $16^{\circ} \mathrm{C}$ surface temperature. Arctica islandica from the German Bight and Iceland and A. opercularis were transported in cooled containers to the Alfred-Wegener Institute for Polar and Marine Research in Bremerhaven. Bivalves were acclimated for 2 months at $10^{\circ} \mathrm{C}$ and $33 \mathrm{PSU}$ in $60-1$ aquaria with recirculating sea water containing $10 \mathrm{~cm}$ of pea gravel sediment. All bivalves were fed once a week with DT-live marine plankton (DT, USA, $3 \mathrm{ml}$ bivalve $^{-1}$ week $^{-1}$ ).

\section{Measurement of proliferation rates}

The measurement of proliferation rates in bivalve tissues was modified after Moore et al. (1994). For labelling with proliferation reagents, 5 German Bight $A$. islandica, 15 Iceland $A$. islandica of different age classes, and 5 A. opercularis were exposed individually in 3-1 flasks filled with natural seawater (33 PSU) at constant water temperatures of $10^{\circ} \mathrm{C}$. Three days prior to incubation, experimental bivalves were not fed any more to avoid eutrophication through faeces and microbial contamination of the incubation water. 5-Bromo-2-deoxyuridine (BrdU, Fluka, $30 \mathrm{mg}^{-1}$ ) and 5-Fluoro-2-deoxyuridine (FdU, Fluka, 
$3 \mathrm{mg} \mathrm{l}^{-1}$ ) were dissolved in the experimental water and taken up by the bivalves with the inhaled medium. 5-Fluoro-2-deoxyuridine reduces competition with endogenous thymidine and increases BrdU incorporation. Duration of exposure of A. opercularis was $24 \mathrm{~h}$, and because of slower proliferation rates incubation time of Iceland and German Bight A. islandica was prolonged to 5 days. During the 5-days A. islandica-incubation, 1.51 of the experimental medium was exchanged with an equal amount of freshly prepared BrdU and FdU seawater every $24 \mathrm{~h}$. Control bivalves were held in seawater without proliferation reagents. Bivalves were dissected and blocks of gill, mantle, adductor muscle and heart tissue transferred to cryovials and snap frozen in liquid nitrogen for both proliferation and apoptosis measurements. The shells of all bivalves were cleaned and numbered for individual age determination. Tissue blocks were embedded on chucks using frozen section medium (Neg-50, Thermo Fisher Scientific, Waltham, USA) and cut with a cryostat HM 500 OM (MICROTOM GmbH, Walldorf, Germany) at $-20^{\circ} \mathrm{C}$ in 1- $\mu \mathrm{m}$-thick cryo-sections, which were placed on BioBond (BBInternational, West Chester, USA) coated slides. Cryosections were stained with anti-BrdU and diaminobenzidine (DAB) using an Amersham cell proliferation kit (GE Healthcare, Buckinghamshire, UK) with three changes to the standard protocol: (1) before rehydration, sections were fixed for $30 \mathrm{~s}$ in $100 \%$ acetone, washed 3 times in phosphate-buffered saline (PBS) and incubated $3 \mathrm{~min}$ in $3 \% \mathrm{H}_{2} \mathrm{O}_{2}$, (2) $50 \mathrm{mM}$ Tris- $\mathrm{HCl}$ buffer $(50-\mathrm{mM}$ Tris, 146-mM NaCl, 200-mM $\mathrm{HCl}$ ) was used instead of PBS before staining with DAB, (3) eosin-phloxin solution was used to counterstain the chromogen for $30 \mathrm{~s}$, this was followed by 6 dips in 80\% ethanol, 10-min dehydration and embedding of the sections in Euparal (CHROMAGESELLSCHAFT, 3C 239). Method controls were prepared from tissues of control bivalves and not labelled with BrdU, and tissues labelled with BrdU but using PBS to replace the primary antibody. A second cryosection of each sample was stained in haematoxylin and eosin-phloxin (H\&E) to visualise all nuclei in the tissue section. Cryosections were analysed with a Zeiss Axioscope light microscope equipped with a KS300 image analysis software to count both nuclei stained by H\&E $\left(N_{\mathrm{H} \& \mathrm{E}}\right)$ and dividing nuclei stained with the Amersham cell proliferation kit $\left(N_{\mathrm{P}}\right)$. Per cent cell proliferation day ${ }^{-1}$ was calculated as:

$\%$ proliferation $24 h^{-1}=N_{\mathrm{P}} / N_{\mathrm{H \& E}} \times 100$ $\times$ day of incubation ${ }^{-1}$

Measurement of caspase- 3 and -7 activities

The measurement of apoptosis via caspase- 3 and -7 activity was modified after Liu et al. (2004). Frozen samples of mantle, gill and adductor muscle of 5 German Bight A. islandica, 15 Iceland A. islandica of different age classes, and 5 A. opercularis were ground in liquid nitrogen and homogenised with a glass homogeniser (Nalgene, USA) in lysis buffer (100-mM HEPES, pH 7.5, 5-mM $\mathrm{MgCl}_{2}$, 1 -mM EGTA, and $1 \mu \mathrm{g} \mathrm{ml}^{-1}$ each leupeptin, pepstatin and aprotinin) $1: 100(\mathrm{w} / \mathrm{v})$. Homogenates were centrifuged for $15 \mathrm{~min}$ at $15000 \mathrm{~g}$ and $4^{\circ} \mathrm{C}$, and apoptosis intensities in supernatants were determined as caspase- 3 and -7 activities using a Caspase-Glo 3/7 Assay kit (Promega, Madison, USA). The assay provides a luminogenic caspase- $3 / 7$ substrate, diluted in a reagent optimised for caspase activity, luciferase activity and cell lysis. Equal volumes of reagents and supernatant were added to a white-walled 96well plate and incubated at $25^{\circ} \mathrm{C}$ for $1 \mathrm{~h}$. The proluminescent substrate was cleaved by caspases and extracted into the supernatant, where it formed a substrate for luciferase. The resulting luminescence signal is proportional to the amount of caspase activity present in the supernatant. Samples were analysed using a Multilabel Reader LB 941 TriStar (Berthold Technologies GmbH \& Co.KG, Bad Wildbad, Germany) which gave luminescence readings as relative light units (RLU). Subsequently, protein concentration was determined in the supernatant according to Bradford (1976) and apoptosis intensities expressed as RLU $\mathrm{mg}^{-1}$ protein.

\section{Measurement of superoxide dismutase activity}

German Bight and Iceland A. islandica were dissected and gill and mantle tissues snap frozen in liquid nitrogen for enzyme activity measurements. Shells of all bivalves were collected for individual age determination. Superoxide dismutase (SOD) activity was determined after Livingstone et al. (1992). 100-180 mg of frozen mantle and gill tissue were ground in liquid nitrogen and homogenised with a micropistill in Tris- $\mathrm{HCl}$ buffer (20mM TRIS, 1-mM EDTA, 20-mM HCl, pH 7.6) 1:10 (w/v). Samples were centrifuged for $3 \mathrm{~min}$ at $18000 \mathrm{~g}$ and $4^{\circ} \mathrm{C}$. SOD activity was measured as degree of inhibition of the reduction of cytochrome $c$ by superoxides generated by a xanthine oxidase/xanthine system at $550 \mathrm{~nm}$ in $43-\mathrm{mM}$ potassium buffer with 0.1-mM EDTA, $\mathrm{pH}$ 7.8. One unit SOD causes $50 \%$ inhibition under assay conditions. Mitochondrial and cytosolic SOD isoforms were not distinguished.

Measurement of catalase activity

Catalase (CAT) activity was determined after Aebi (1984). In phosphate buffer $\left(50-\mathrm{mM} \mathrm{KH}_{2} \mathrm{PO}_{4}, 50-\mathrm{mM} \mathrm{Na}_{2} \mathrm{HPO}_{4}\right.$, $\mathrm{pH} 7.0$ ) with $0.1 \%$ Triton $\mathrm{x}-100$ at $1: 30$ (w/v), 20-50 mg of frozen mantle and gill tissue were ground in liquid nitrogen 
and homogenised with a micropistill. Samples were centrifuged for $15 \mathrm{~min}$ at $13000 \mathrm{~g}$ and $4^{\circ} \mathrm{C}$, and CAT activity was determined by recording the period required for $\mathrm{H}_{2} \mathrm{O}_{2}$ decomposition, resulting in a decrease in absorption from 0.45 to 0.4 at $240 \mathrm{~nm}$ (1 unit).

\section{Calculation of respiration and metabolic rate}

Respiration rates of German Bight and Iceland A. islandica were measured at $10^{\circ} \mathrm{C}$ in a multichannel intermittent flow system as described by Begum et al. (2009) and Heilmayer and Brey (2003). To eliminate the impact of specific dynamic action (SDA) on respiration, bivalves were maintained without food for three days (Bayne et al. 1976), and measured separately after one night in the respiration chamber. Oxygen concentration was monitored continuously with fluorescein-coated oxygen microoptodes (PSt1-L5-TF, PreSens, Neuweiler, Germany) connected to a MICROX TR3 array (PreSens, Neuweiler, Germany). After the measurement, clams were dissected and soft tissue dried at $68^{\circ} \mathrm{C}$ for at least $48 \mathrm{~h}$ to determine dry mass (DM). To obtain ash-free dry mass (AFDM = $\mathrm{DM}$ - ash), dried tissues of $A$. islandica were combusted for $24 \mathrm{~h}$ at $500^{\circ} \mathrm{C}$. Oxygen consumption rates $\left(\mathrm{VO}_{2}, \mu \mathrm{mol}\right.$ $\mathrm{O}_{2} \mathrm{~h}^{-1}$ ind $^{-1}$ ) and mass specific respiration rates (MSR, $\mu \mathrm{mol} \mathrm{O}_{2} \mathrm{~h}^{-1}$ ind $^{-1} \mathrm{AFDM}^{-1}$ ) were calculated according to Begum et al. (2009). Shells of all bivalves were cleaned and numbered for individual age determination.

\section{Age determination}

Age determination for A. islandica was carried out as described by Schöne et al. (2004) and Strahl et al. (2007). Briefly, the right shell was embedded in epoxy resin and sectioned along the axis of maximum shell growth (height $H$ ) with a Buehler low-speed diamond saw. Cross-sections were ground and polished and annual shell growth bands were counted using a stereomicroscope at 10 - to 80 -fold magnification. In A. opercularis, individual age was inferred from shell height and a von Bertalanffy growth model (VBGM) established by Heilmayer et al. (2004) and based on height-at-age-data of the same scallop population from the English Channel. The von Bertalanffy growth function (VBGF):

$H_{t}=H_{\infty} \times\left(1-e^{-k \times\left(t-t_{0}\right)}\right)$

was used to model the relation between shell height and age, where $H_{t}$ is height at age $t, H_{\infty}$ is height at infinite age, $\mathrm{k}$ is the growth constant and $t_{0}$ is age at which size would be zero. To estimate age $t$ from height of our experimental clams, we fitted the inverse VBGF: $t=\ln \left(1-H_{t} / H_{\infty}\right) /-k+t_{0}$

Statistical analysis

Proliferation rates were transformed according to: $\arcsin$ $\sqrt{\% \text { proliferating cells } 24 \mathrm{~h}^{-1} 100^{-1}}$. Statistical analyses were performed with GraphPad Prism 5 Software (La Jolla, California, USA). Mass specific respiration rates, superoxide dismutase and catalase activity, and proliferation rates and apoptosis intensities of all three populations were tested for normality (Kolmogorov-Smirnov test) and homogeneity of variances (Bartlett's test). One-way ANOVA (KruskalWallis test for non-Gaussian distributed data) with post-hoc test Tukey (Dunn's) was used to test for differences in mass specific respiration and superoxide dismutase and catalase activity in mantle and gill within the three populations. Oneway ANOVA (Kruskal-Wallis test for no Gaussian distributed data) with post-hoc test Tukey (Dunn's) was used to test for differences in proliferation rates and apoptosis intensities between tissues within one population and between three age groups within one tissue type. Two-way ANOVA and Bonferroni post-hoc test were used to test whether tissue type, species/population and age differentially affects proliferation rates or apoptosis intensities in different populations. Slopes of linear regressions were tested for deviation from zero with an $F$-test (proliferation rates and apoptosis intensities versus age for each tissue of all three populations).

\section{Results}

Proliferation rates and apoptotic intensity in tissues of Arctica islandica and Aequipecten opercularis

Proliferating cells were detected in mantle, gill, adductor muscle and heart of the two investigated species (Fig. 1). Proliferation rates and ratios between tissues were similar in German Bight (GB) and Iceland (IC) Arctica islandica, with slightly higher proliferation values in IC clams. GB A. islandica had significantly higher proliferation rates in gill tissue $(0.8 \pm 0.6 \%$ cell division in $24 \mathrm{~h})$ compared to values $<0.1 \%$ cell division in $24 \mathrm{~h}$ in mantle and heart muscle (One-way ANOVA $P<0.0001$, Tukey $P<0.01$ ). Proliferation rates in GB A. islandica adductor muscle were below detection limit $(=0 \%)$ after 5 days of BrdU incubation. IC A. islandica mantle and gills had highest proliferation rates with around $1 \%$ of nuclei dividing in $24 \mathrm{~h}$, followed by the heart muscle and significantly lower rates in adductor muscle with $0.22 \pm 0.30 \%$ cell division in $24 \mathrm{~h}$ (Kruskal-Wallis $P<0.001$, Dunn's $P<0.01$, Fig. 2, arcsin transformed data are shown). Proliferation rates were significantly higher in all tissues of the scallop Aequipecten opercularis compared to GB and IC A. islandica (Two-way 
Fig. 1 Proliferating cell nuclei in cryo slices of mantle $(\mathbf{a}, \mathbf{e})$, gill $(\mathbf{b}, \mathbf{f})$, adductor muscle $(\mathbf{c}, \mathbf{g})$ and heart $(\mathbf{d}, \mathbf{h})$ of Icelandic Arctica islandica (left) after 5 days of BrdU incubation vs. Aequipecten. opercularis from the English Channel (right) after $24 \mathrm{~h}$ of BrdU incubation. BrdUlabelled nuclei appear black

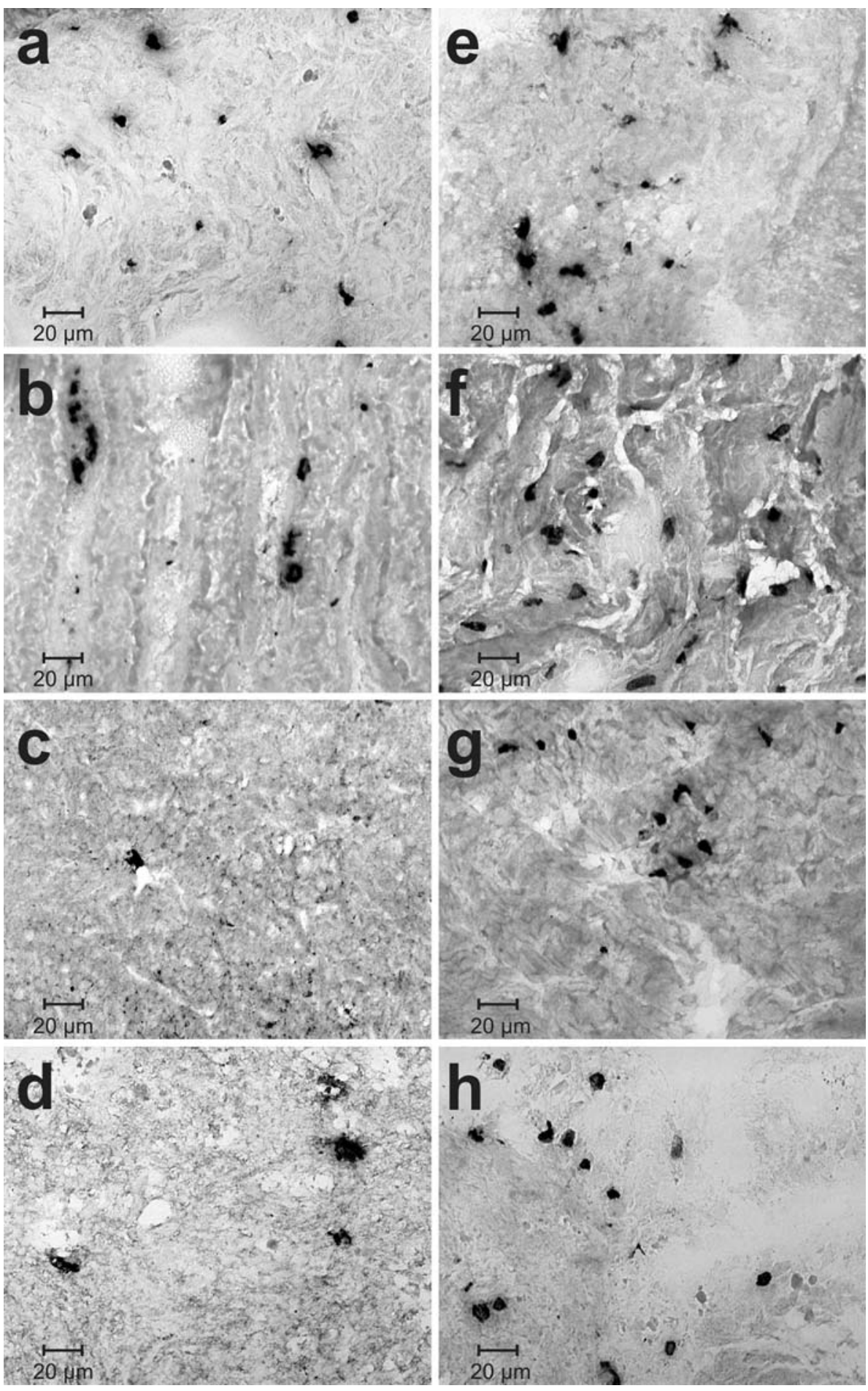

ANOVA $P<0.0001 ;$ arcsin transformed data are given in Fig. 2). In gill tissue of A. opercularis, $12.3 \pm 7.9 \%$ of nuclei were dividing within $24 \mathrm{~h}$, whereas mantle, adductor muscle and heart were less actively proliferating without significant differences between scallop tissues. Apoptosis intensities within one tissue type were higher in A. opercularis compared to either GB or IC A. islandica, but only in adductor inter-specific differences were significant, with tenfold higher values in A. opercularis (One-way ANOVA $P<0.0001$, Tukey $P<0.001$, Fig. 3). Mantle tissue had 3-times and gill 1.5-times higher apoptosis rates in A. opercularis compared to A. islandica. In the tissue comparison, highest apoptotic activity was observed in scallop gills, followed by adductor muscle and mantle. Again, differences were not statistically significant. Apoptosis intensity in gills of both GB and IC A. islandica 


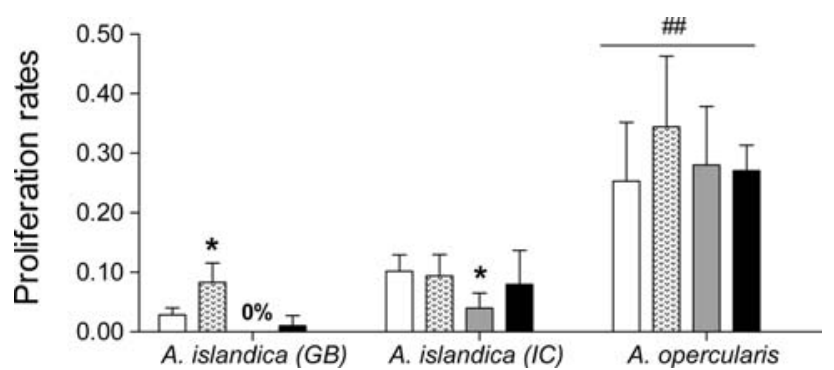

Fig. 2 Proliferation rates in $\arcsin \sqrt{ }\left(\%\right.$ proliferating cells $24 \mathrm{~h}^{-1}$ $100^{-1}$ ) in mantle (open bars), gill (dotted bars), adductor muscle (shaded bars) and heart (filled bars) of German Bight (GB) Arctica islandica (means $\pm \mathrm{SD}, n=5$ per tissue type), Icelandic (IC) $A$. islandica (means $\pm \mathrm{SD}, n=15$ per tissue type) and Aequipecten opercularis from the English Channel (means $\pm \mathrm{SD}, n=5$ per tissue type). \#\# Significant differences in tissues of A. opercularis compared to GB and IC A. islandica (Two-way ANOVA $P<0.0001$ ). * Gill differs significantly from all other tissues in GB A. islandica (Oneway ANOVA $P<0.0001$; Tukey $P<0.01$ ) and adductor muscle differs significantly from all other tissues in IC A. islandica (KruskalWallis $P<0.001$; Dunn's $P<0.01)$. $0 \%$ : cell proliferation rate is zero in the adductor muscle of GB A. islandica

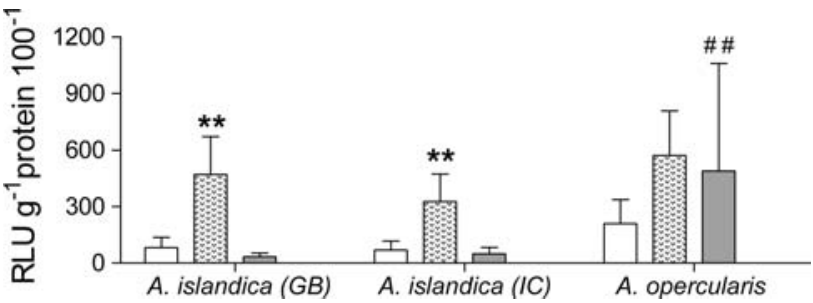

Fig. 3 Apoptosis intensities (RLU g ${ }^{-1}$ protein $100^{-1}$ ) in mantle (open bars), gill (dotted bars) and adductor muscle (shaded bars) of German Bight (GB) Arctica islandica (means $\pm \mathrm{SD}, n=5$ per tissue type), Icelandic (IC) A. islandica (means $\pm \mathrm{SD}, n=15$ per tissue type) and Aequipecten opercularis from the English Channel (means $\pm \mathrm{SD}$, $n=5$ per tissue type). \#\# Significant differences in adductor muscle between $A$. opercularis vs both $A$. islandica populations (One-way ANOVA $P<0.0001$, Tukey $P<0.001)$. ** Significant differences in gill compared to other tissues of IC and GB A. islandica (One-way ANOVA $P<0.0001$; Tukey $P<0.001$ )

ranged significantly higher than in mantle and adductor muscle, with eightfold lower values in adductor muscle and fivefold lower values in mantle (One-way ANOVA $P<0.0001$, Tukey $P<0.001$, Fig. 3).

Proliferation rates and apoptosis intensities in tissues of Icelandic Arctica islandica over an age range of 7-148 years

Proliferation rates decreased significantly with increasing age in the heart muscle of IC A. islandica (proliferation: Oneway ANOVA $P<0.01$; Tukey $P<0.05$; Fig. 4 , arcsin transformed data are shown). Proliferation in the heart was 20 times lower in 118-145 years old clams than in young individuals of 7-10 years. Average rates in young clams were $1.93 \pm 1.22 \%$ of proliferating heart cells in $24 \mathrm{~h}$

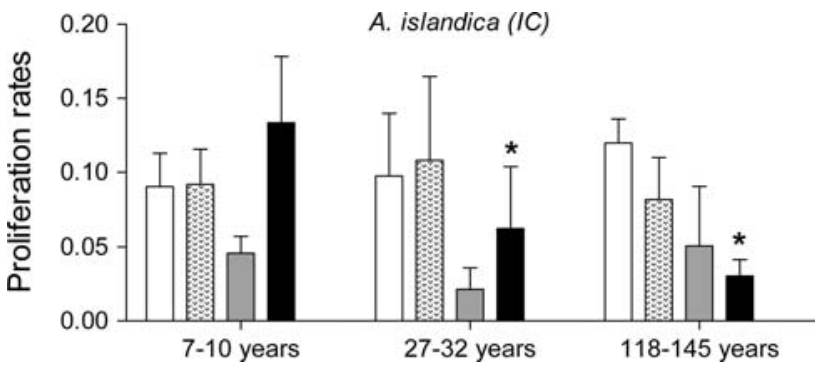

Fig. 4 Proliferation rates in $\arcsin \sqrt{ }\left(\%\right.$ proliferating cells $24 \mathrm{~h}^{-1}$ $100^{-1}$ ) in mantle (open bars), gill (dotted bars), adductor muscle (shaded bars) and heart (filled bars) of young (7-10 years), middleaged (27-32 years) and old (118-145 years) Icelandic (IC) Arctica islandica (means $\pm \mathrm{SD}, n=5$ per tissue type and age class). * Significant differences between heart of middle aged and old compared to young individuals (One-way ANOVA $P<0.01$; Tukey $P<0.05$ )

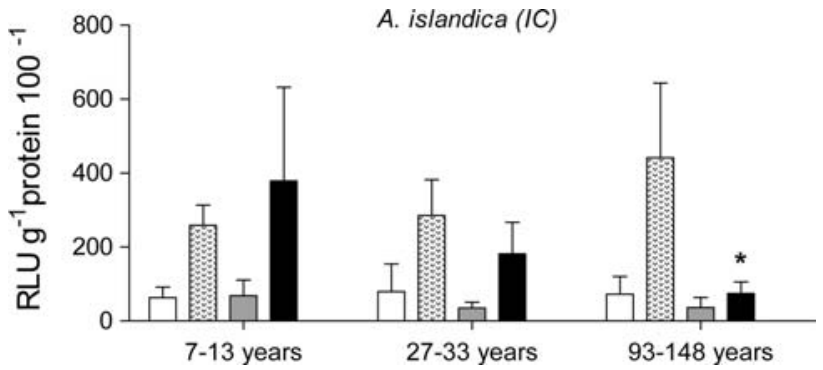

Fig. 5 Apoptosis intensities ( $R L U g^{-1}$ protein $100^{-1}$ ) in mantle (open bars), gill (dotted bars), adductor muscle (shaded bars) and heart (filled bars) of young (7-10 years), middle-aged (27-32 years) and old (118-145 years) Icelandic (IC) Arctica islandica (means \pm $\mathrm{SD}, n=5$ per tissue type and age class). $*$ Significant difference between heart of old compared to young individuals (One-way ANOVA $P<0.05$; Tukey $P<0.05$ )

compared to $0.52 \pm 0.49 \%$ in middle aged (27-32 years) and $0.10 \pm 0.07 \%$ in old individuals (118-145 years) (linear regression $P<0.05$ Fig. $6 \mathrm{a}$, arcsin transformed data are shown). Also, apoptosis intensities decreased significantly with age in the heart muscle of IC A. islandica (apoptosis: One-way ANOVA $P<0.05$; Tukey $P<0.05$; Fig. 5). Apoptotic intensity ranged highest in heart tissue of young ocean quahog and was five-times lower in bivalves $>100$ years old (linear regression $P<0.05$, Fig. 6b). In contrast to the heart values, proliferation rates and apoptotic activity in mantle, gill and adductor muscle of $A$. islandica were the same over an age range of 7-148 years (Figs. 4, 5).

Respiration rates and antioxidant enzyme activities in tissues of Arctica islandica and Aequipecten opercularis

Mass specific respiration rate (MSR) was significantly lower in GB and IC A. islandica compared to A. opercularis from the English Channel (Kruskal-Wallis $P<0.001$, Dunn's $P<0.005)$, which showed twice as high MSR. IC 
Fig. 6 a Proliferation rates in $\arcsin \sqrt{ }(\%$ proliferating cells $\left.24 \mathrm{~h}^{-1} 100^{-1}\right)$ (filled circles) $(y=-0.0007 x+0.117$

$\left.r^{2}=0.462 ; n=13\right)$ and b Apoptosis intensities in RLU g ${ }^{-1}$ protein $100^{-1}$ (open circles $)(y=-2.295 x+329.1$ $\left.r^{2}=0.2907 ; n=15\right)$ in heart of Icelandic Arctica islandica
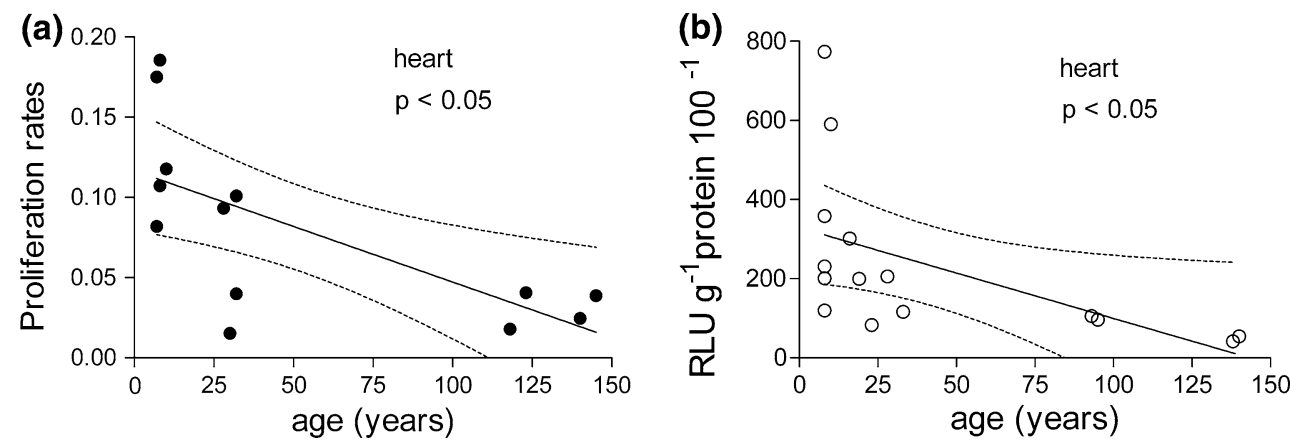

A. islandica had slightly higher MSR than GB clams, but differences were not statistically significant (Table 1). In contrast, both superoxide dismutase (SOD) and catalase (CAT) activity were significantly higher in mantle tissue of GB and IC A. islandica compared to A. opercularis (Kruskal-Wallis $P<0.0001$, Dunn's $P<0.05$ ). SOD activity was twice as high in both $A$. islandica populations compared to A. opercularis. CAT activity was six-times higher in GB A. islandica and seven-times higher in IC A. islandica than in A. opercularis. No significant differences were detected in mantle or gill between the two A. islandica populations for either enzyme (Table 1).

\section{Discussion}

We compared two bivalve model species, the long-lived and slow-growing ocean quahog Arctica islandica and the short-lived and fast-growing scallop Aequipecten opercularis. In the case of the Icelandic ocean quahog, we could distinguish between age groups, whereas our entire sample of A. opercularis comprised 2-4 years old mature individuals still in the phase of highest growth. Von Bertalanffy growth models for A. opercularis from the English Channel

Table 1 Investigated age range in year, mass specific respiration rate (MSR) in $\mu \mathrm{mol} \mathrm{O}_{2} \mathrm{~h}^{-1}$ ind $^{-1} \mathrm{AFDM}^{-1}$ and antioxidant enzyme activity of superoxide dismutase (SOD) and catalase (CAT) in $\mathrm{U} \mathrm{g}^{-1} \mathrm{WM}$ in tissues of German Bight (GB) and Iceland (IC) Arctica demonstrate highest shell growth rates in conjunction with highest somatic production between 0 and 2 years of age, whereas from the 5th year on growth rates become asymptotic (Heilmayer et al. 2004). Rapid growth in young and mature A. opercularis of up to 4 years is in agreement with higher proliferation and cell turnover rates in tissues of the scallops compared to the ocean quahog. Rapid proliferation, especially in tissues such as the voluminous adductor muscle, cannot represent net-growth efficiency, because a muscle growth of $10 \%$ day $^{-1}$ would exceed the slower shell growth within days. Indeed, high proliferation is in part counterbalanced by a high intensity of programmed cell death. Next to early sexual maturation, starting at the age of $<1$ year (Román et al. 1996), shortlived A. opercularis are characterised by rapid cell turnover in somatic tissues, which explains the higher basic energy demand indicated by high mass specific respiration (MSR) compared to more slowly growing A. islandica. According to the 'Free-Radical-Rate-of-living' theory of Pearl (1928) and Harman (1956), high oxygen turnover would suggest a high formation rate of reactive oxygen species (ROS) in the mitochondria. This could cause accelerated ageing and therefore be one reason why life span is limited to 10 years in A. opercularis (Ansell et al. 1991). However,

islandica and Aequipecten opercularis from the English Channel (MSR: $n=20-31$ for each population/species, SOD/CAT: $n=6-11$ for each population/species)

\begin{tabular}{|c|c|c|c|}
\hline & A. islandica $(\mathrm{GB})$ & A. islandica (IC) & A. opercularis ${ }^{\mathrm{a}}$ \\
\hline Age & $33-98$ & $29-141$ & $1-6$ \\
\hline MSR & $2.46 \pm 0.40$ & $4.05 \pm 1.83$ & $8.32 \pm 3.91 * *$ \\
\hline SOD gill & $728.62 \pm 226.10$ & $809.97 \pm 406.53$ & $-{ }^{\mathrm{b}}$ \\
\hline SOD mantle & $790.04 \pm 430.61$ & $658.22 \pm 364.18$ & $379 \pm 169 *$ \\
\hline CAT gill & $2,944.35 \pm 1,016.08$ & $3,526.23 \pm 740.30$ & $-{ }^{\mathrm{b}}$ \\
\hline CAT mantle & $2,939.07 \pm 633.21$ & $2,330.51 \pm 452.43$ & $384 \pm 69 * *$ \\
\hline
\end{tabular}

** Significant differences in MSR and CAT in mantle of A. opercularis compared to GB and IC A. islandica (Kruskal-Wallis $P<0.0001$, Dunn's $P<0.001)$

* Significant differences in SOD in mantle of A. opercularis compared to GB and IC A. islandica (Kruskal-Wallis $P<0.0001$, Dunn's $P<0.05)$

${ }^{a}$ Data for A. opercularis from Philipp et al. (2006), SOD and CAT activity recalculated in $\mathrm{U} \mathrm{g} \mathrm{WM}^{-1}$

b No data available 
mitochondrial production of ROS is hardly measurable in $A$. opercularis and ranged tenfold higher under the same assay conditions in A. islandica (Philipp et al. 2006, 2008; S. Hardenberg, D. Abele, unpublished data). Thus, scallops have higher mitochondrial respiration, but control ROS generation in tissues at extremely low levels, which presumably protects them from severe oxidative damage during frequent phases of exhaustive swimming. To conserve these low ROS levels over lifetime, A. opercularis eliminate damaged mitochondria from adductor muscle cells during ageing (Philipp et al. 2008). Permanent elimination of damaged mitochondria through intensive apoptosis is in keeping with absence of mitochondrial ageing in $A$. opercularis, and mitochondrial respiration and energetic coupling indeed do not change with age (Philipp et al. 2006).

Proliferation and apoptosis also eliminate oxidative waste products such as the fluorescent age pigment lipofuscin and protein carbonyls. Highest tissue cell turnover rates occur in gills of $A$. islandica and A. opercularis, possibly triggered by oxidative damage. The gill is one of the most active tissues and ROS production in this organ is assumed to be high. Accordingly, studies of lipofuscin accumulation in different tissues of the ocean quahog indicated better tissue protection and maintenance in adductor muscle and mantle compared to gills, where the age pigments were most highly concentrated (Strahl et al. 2007).

Arctica islandica is not only the longest lived bivalve known today, but moreover one of the slowest growing bivalves worldwide (Strahl et al. 2007). In addition to low MSR, slow gonad ripening and late onset of maturation at ages of 10-14 years in the ocean quahog (Thompson et al. 1980), slow cell proliferation and growth are additional criteria characterising long-lived species (Bauer 1992; Mangel 2003). These slow rates of cell division enable individual cells in ocean quahog tissues to grow to large diameters. Muscle fibre diameter increased fourfold in old ( $>100$ years) compared to young clams $(<10$ years, Strahl et al. 2007). At the same time, low proliferation and cell turnover rates suggest that $A$. islandica cells should be endowed with an efficient system of waste removal through proteasomal and autophagic processes, and a well-established antioxidant defence system, to offset accumulation of cellular oxidative damage. Indeed, we found high and stable antioxidant protection in tissues of the ocean quahog between 30 and 200 years (Abele et al. 2008), whereas A. opercularis has a low investment in cellular protection and maintenance at advanced age (Philipp et al. 2006). Similarly, in the oyster Crassostrea virginica with a maximal live span (MLSP) of only 6 years, not only antioxidant enzyme activity was lower but, the density of apoptotic and mitotic cells was also diminished in gill, adductor muscle and heart of mature compared to young oysters (Ivanina et al. 2008; Sunila and LaBanca 2003). It would be interesting to see whether in short-lived scallops the reported shift in energy allocation from somatic maintenance towards reproduction at the end of life (see also Heilmayer et al. 2004; Abele et al. 2009) leads to reductions of cell proliferation in somatic tissues, and whether or not this is accompanied by a decline of apoptotic activity. On the other hand, low metabolic activity and sustained protection from oxidative damage over age, in combination with slow but continued cell turnover, presumably slow senescent decline in A. islandica. Long-lived molluscs are known to budget lifetime energy investments equally between somatic maintenance and persistent but slow rates of gametogenesis (Arntz et al. 1994) and the lifelong continued damage repair and cell turnover explains negligible senescence in longlived species (Kirkwood 2005; Ebert 2008).

The present study indicates negligible evidence of senescence in the mantle, gill and adductor muscle, whereas proliferation and apoptosis in the heart of $A$. islandica decreased dramatically with age. Since studies in the 1920 s reported difficulties in detecting dividing cells or mitosis in the human heart (Karsner et al. 1925), the adult heart was regarded as postmitotic tissue. In contrast, we found proliferating heart cells in mature scallops and ocean quahog of all age classes, which is in line with more recent studies on vertebrates and suggests that heart cells of vertebrates and invertebrates can proliferate until old age and thus regenerate heart functions to some extent (Anversa et al. 1991; Kajstura et al. 1998; Poss et al. 2002). However, decreasing cell turnover rates over a lifetime of 140 years in the ocean quahog heart were indeed the only symptoms of old age indicating less-active cell renewal through proliferation and less-efficient removal of damaged cells. This in turn may indicate higher damage levels and possibly ongoing loss of function in the heart of ageing $A$. islandica. Impaired cardiac function has been suggested to limit life span in mammals (Leri et al. 2003) and perhaps 'heart failure' could finally cause natural death in old ocean quahog.

Our second question was whether geographically distant populations of $A$. islandica from the German Bight and from Iceland, that differ by at least 100 years in the recorded maximum age (Begum et al. 2009), are also physiologically distinct. Our measurements documented no significant differences between the two populations for proliferation, apoptosis, respiration rates and antioxidant protection. Thus, a difference of $5^{\circ} \mathrm{C}$ in bottom habitat temperature between the southern North Sea and the North Iceland fishing grounds was not accompanied by differences in ocean quahog physiology that would explain the shorter life span of A. islandica in warmer North Sea waters. This contrasts with other studies which, either by comparing latitudinal populations of the same species (Ziuganov et al. 2000) or bivalves from similar habitats in temperate and polar habitats (Philipp 
et al. 2005a, b, 2006), document longer life span and slower change of physiological parameters with age in the coldadapted populations/species. Similar physiological capacities are, however, consistent with observations of a low level of genetic differentiation between climatically distinct A. islandica populations throughout the NE Atlantic (Dahlgren et al. 2000; Begum et al. in prep).

Age-dependent measurements of physiological parameters in German Bight $A$. islandica would have allowed a comparison of trends with age with the Icelandic population, but were impossible, because individuals $<30$ years old are missing, and older individuals $>100$ years are rarely encountered in the German Bight. Instead, our sample was limited to 32-98 years old clams with an average shell height of $74 \pm 5 \mathrm{~mm}$. The narrow age range was earlier reported by Witbaard and Bergman (2003) who studied populations in the south-eastern North Sea between 1990 and 2000 and found them dominated by adults of 50$85 \mathrm{~mm}$ shell height, whereas young clams of smaller size were extremely rare. The relative absence of young individuals either indicates problems with larval settlement and recruitment, or high mortality rates of very young A. islandica during the past 35 years in the southern North Sea (Witbaard and Bergman 2003). An important impact comes from beam trawl fishery which caused a general decline in the number of benthic bivalves in the past 100 years in the southern North Sea (Rumohr and Kujawski 2000) and mainly affects young A. islandica (Witbaard and Klein 1994). Moreover, environmental change in the German Bight area, including strong eutrophication in the 1960s-1990s (Rijinsdorp and van Leeuwen 1996) and slow but steadily increasing water temperatures around Helgoland (Wiltshire and Manly 2004), could cause thinning of the A. islandica population and the reduction of individual life expectancy. Indeed, conditions around Iceland are more favourable in many respects including food availability and absence of severe fishery impacts (Witbaard et al. 1999; Kaiser et al. 2006), which explains the higher densities of Iceland A. islandica (Ragnarsson and Thórarinsdottier 2002; Witbaard and Bergman 2003).

Our study suggests that maximum life expectancy in longlived ocean quahog populations is mainly constrained by environmental impacts in different areas and does not reflect differences in the basic physiology and cellular renewal capacities between North Sea and Iceland A. islandica. Low metabolic rates and slow but stable cell turnover in tissues of Iceland A. islandica over 140 years, combined with high antioxidant protection with age, characterised the long-lived and slow-growing ocean quahog in both regions. In contrast, the short-lived and fast-growing scallop A. opercularis is characterised by high-energy throughput, reduced investment in cellular protection and high proliferation and apoptosis intensities. Low rates of cell proliferation and apoptosis in the heart of Iceland A. islandica were the only symptoms of old age which may indicate higher damage levels and ongoing loss of function. Future studies of ageing in molluscs should look into cellular viability and oxidative stress parameters in the heart.

Acknowledgments We thank Gudmundur Vidir Helgasson, Halldór Pálmar Halldórsson and Reynir Sveinsson from Sandgerdi Marine Station (University of Iceland) as well as Siggeir Stefánsson and Silvia Hardenberg for support during the field work in Iceland. Thanks to Michael Janke and the Uthoern crew for fishing North Sea A. islandica, Sabine Schaefer who helped with the immuno-histochemical techniques, and Stefanie Meyer and Kerstin Beyer who technically supported our study. The cooperative project between the working groups of PD Dr. Abele (Alfred-Wegener Institute) and Prof. Dr. Dringen (University of Bremen) was financed by the Deutsche Forschungsgemeinschaft (DFG), grant numbers AB124/10-1 and DR262/10-1.

\section{References}

Abele D, Strahl J, Brey T, Philipp E (2008) Imperceptible senescenceageing in the ocean quahog Arctica islandica. Free Radic Res 42:474-480

Abele D, Brey T, Philipp E (2009) Bivalve models of aging and the determination of molluscan lifespan. Exp Gerontol 44:307-315

Aebi H (1984) Catalase in vitro. Methods Enzymol 105:121-126

Ansell AD, Dao J-C, Mason J (1991) Three European scallops: Pecten maximus, Chlamys (Aequipecten) opercularis and C. (Chlamys) varia. In: Shumway SE (ed) Scallops: biology, ecology and aquaculture. Elsevier, Amsterdam, pp 715-751

Anversa P, Fitzpatrick D, Argani S, Capasso JM (1991) Myocyte mitotic division in the aging mammalian rat heart. Cir Res 69:1159-1164

Arntz WE, Brey T, Gallardo VA (1994) Antarctic zoobenthos. Oceanogr Mar Biol Annu Rev 32:241-304

Bauer G (1992) Variation in the life span and size of the freshwater pearl mussel. J Anim Ecol 61:425-436

Bayne BL, Thompson RJ, Widdows J (1976) Physiology I. In: Bayne BL (ed) Marine mussels. Their ecology and physiology. Cambridge University Press, Cambridge, pp 121-206

Begum S, Basova L, Strahl J, Sukhotin A, Heilmeyer O, Philipp E, Brey T, Abele D (2009) A metabolic model for the ocean quahog Arctica islandica-effects of animal mass and age, temperature, saliniy, and geography on respiration rate. J Shellfish Res 28:533-539

Bodnar AG (2009) Marine invertebrates as models for aging research. Exp Gerontol 44:477-484

Bradford MM (1976) A rapid and sensitive method for the quantitation of microgram quantities of protein utilizing the principle of protein-dye binding. Anal Biochem 72:248-254

Dahlgren TG, Weinberg JR, Halanych KM (2000) Phylogeography of the ocean quahog (Arctica islandica): influences of paleoclimate on genetic diversity and species range. Mar Biol 137:487-495

Ebert TA (2008) Longevity and lack of senescence in the red sea urchin Strongylocentrotus franciscanus. Exp Gerontol 43:734-738

Harman D (1956) Aging: a theory based on free radical and radiation biology. J Gerontol 11:298-300

Heilmayer O, Brey T (2003) Saving by freezing? Metabolic rates of Adamussium colbecki in a latitudinal context. Mar Biol 143:477-484

Heilmayer O, Brey T, Storch D, Mackensen A, Arntz WE (2004) Population dynamics and metabolism of Aequipecten opercularis (L.) from the western English Channel (Roscoff, France). J Sea Res 52:33-44 
Ivanina AV, Sokolova IM, Sukhotin AA (2008) Oxidative stress and expression of chaperones in aging mollusks. Comp Biochem Physiol, B 150:53-61

Jones DS (1980) Annual cycle of shell growth increment formation in two continental shelf bivalves and its paleoecologic significance. Paleobiology 6:331-340

Kaiser MJ, Clarke KR, Hinz H, Austen MCV, Sommerfield PJ, Karakassis I (2006) Global analysis of response and recovery of benthic biota to fishing. Mar Ecol Prog Ser 311:1-14

Kajstura J, Leri A, Finato N, Di Loreto C, Beltrami C (1998) Myocyte proliferation in end-stage cardiac failure in humans. Proc Natl Acad Sci USA 95:8801-8805

Karsner HT, Saphir O, Todd TW (1925) The state of the cardiac muscle in hypertrophy and atrophy. Am J Pathol 1:351-371

Kirkwood TBL (2005) Understanding the odd science of aging. Cell 120:437-447

Leri A, Franco S, Zacheo A, Barlucchi L, Chimenti S, Limana F, Nadal-Ginard B, Kajstura J, Anversa P, Blasco MA (2003) Ablation of telomerase and telomere loss leads to cardiac dilatation and heart failure associated with p53 upregulation. Eu Mol Biol Organ 22:131-139

Liu D, Li C, Chen Y, Burnett C, Liu XY, Downs S, Collins RD, Hawiger J (2004) Nuclear import of proinflammatory transcription factors is required for massive liver apoptosis induced by bacterial lipopolysaccharide. J Biol Chem 279:48434-48442

Livingstone DR, Lips F, Garcia Martinez P, Pipe RK (1992) Antioxidant enzymes in the digestive gland of the common mussel Mytilus edulis. Mar Biol 112:265-276

Mangel M (2003) Environment and longevity: the demography of the growth rate. In: Carey JR, Tuljapurkar S (eds) Life span: evolutionary, ecological and demographic perspectives, vol 29. Population Council Inc, New York, pp 57-70

Mann R (1982) The seasonal cycle of gonadal development in Arctica islandica from the southern New England shelf. Fish Bull 80:315-326

Moore JD, Trueman ER (1971) Swimming of the scallop, Chlamys opercularis (L.). J Exp Mar Biol Ecol 6:179-185

Moore MJ, Leavitt DF, Shumate AM, Alatalo P, Stegemann JJ (1994) A cell proliferation assay for small fish and aquatic invertebrates using bath exposure to bromodeoxyuridine. Aquat Toxicol 30:183-188

Murawski SA, Ropes JW, Serchuk FA (1982) Growth of the ocean quahog, Arctica islandica, in the Middle Atlantic Bight. Fish Bull 80:21-34

Nicol D (1951) Recent species of the Veneroid pelecypod Arctica. J Wash Acad Sci 41:102-106

Oeschger R, Storey KB (1993) Impact of anoxia and hydrogen sulphide on the metabolism of Arctica islandica L. (Bivalvia). J Exp Mar Biol Ecol 170:213-226

Pearl R (1928) The rate of living. Alfred Knopf, New York

Philipp EER, Abele D (2009) Masters of longevity: lessons from long-lived bivalves-a mini-review. Gerontology. doi: 10.1159/ 000221004

Philipp E, Brey T, Pörtner H-O, Abele D (2005a) Chronological and physiological ageing in a polar and a temperate mud clam. Mech Ageing Dev 126:589-609

Philipp E, Pörtner H-O, Abele D (2005b) Mitochondrial ageing of a polar and a temperate mud clam. Mech Ageing Dev 126:610-619

Philipp E, Heilmayer O, Brey T, Abele D, Pörtner H-O (2006) Physiological ageing in a polar and a temperate swimming scallop. Mar Ecol Prog Ser 307:187-198

Philipp E, Schmidt M, Gsottbauer C, Sänger AM, Abele D (2008) Size- and age-dependent changes in adductor muscle swimming physiology of the scallop Aequipecten opercularis. J Exp Biol 211: 2492-2501

Poss KD, Wilson LG, Keating MT (2002) Heart regeneration in zebrafish. Science 298:2188-2190
Ragnarsson SA, Thórarinsdottier GG (2002) Abundance of ocean quahog, Arctica islandica, assessed by underwater photography and a hydraulic dredge. J Shellfish Res 21:673-676

Rijinsdorp AD, van Leeuwen PI (1996) Changes in growth of North Sea plaice since 1951 in relation to density, eutrophication, beam-trawl effort, and temperature. ICES J Mar Sci 53:1199-1213

Román G, Campos MJ, Acosta CP (1996) Relationships among environment, spawning and settlement of queen scallop in the Ría de Arosa (Galicia, NW Spain). Aquacult Int 4:225-236

Rumohr H, Kujawski T (2000) The impact of trawl fishery on the epifauna of southern North Sea. ICES J Mar Sci 57:1389-1394

Schöne BR, Freyre Castro AD, Fiebig J, Houk SD, Oschman W, Kröncke I (2004) Sea surface water temperatures over the period 1884-1983 reconstructed from oxygen isotope ratios of a bivalve mollusk shell (Arctica islandica, southern North Sea). Palaeogeogr Palaeoclimatol Palaeoecol 212:215-232

Schöne BR, Houk SD, Freyre Castro AD, Fiebig J, Oschman W (2005) Daily growth rates in shells of Arctica islandica: assessing sub-seasonal environmental controls on a long-lived Bivalve Mollusk. Palaios 20:78-92

Sokolova IM (2009) Apoptosis in molluscan immune defence. ISJ 6:49-58

Sokolova IM, Evans S, Hiughes FM (2004) Cadmium-induced apoptosis in oyster hemocytes involves disturbance of cellular energy balance but no mitochondrial permeability transition. J Exp Biol 207:3369-3380

Strahl J, Philipp E, Brey T, Broeg K, Abele D (2007) Physiological aging in the Icelandic population of the ocean quahog Arctica islandica. Aquat Biol 1:77-83

Sunila I, LaBanca J (2003) Apoptosis in the pathogenesis of infectious diseases of the eastern oyster Crassostrea virginica. Dis Aquat Org 56:163-170

Taylor AC (1976) Burrowing behaviour and anaerobiosis in the bivalve Arctica islandica (L.). J Mar Biol Assoc UK 56:95-109

Thompson I, Jones DS, Ropes JW (1980) Advanced age for sexual maturity in the ocean quahog Arctica islandica (Mollusca: Bivalvia). Mar Biol 57:35-39

Waller TR (1991) Evolutionary relationships among commercial scallops (Mollusca: Bivalvia: Pectinidae). In: Shumway SE (ed) Scallops: biology, ecology and aquaculture. Elsevier, Amsterdam, pp 1-72

Wanamaker AD, Heinemeier J, Scourse JD, Richardson CA, Butler PG, Eiríksson J, Knudsen KL (2008) Very long-lived mollusk confirm 17th century ad tephra-based radiocarbon reservoir ages for north Icelandic shelf waters. Radiocarbon 50:399-412

Wiltshire KH, Manly BFJ (2004) The warming trend at Helgoland roads, North Sea: phytoplankton response. Helgol Mar Res 58:269-273

Witbaard R, Bergman MJN (2003) The distribution and population structure of the bivalve Arctica islandica L. in the North Sea: what possible factors are involved? J Shellfish Res 50:11-25

Witbaard R, Klein R (1994) Long-term trends on the effects of the southern North Sea beam trawl fishery on the bivalve mollusc Arctica islandica L. (Mollusca, Bivalvia). ICES J Mar Sci 51:99-105

Witbaard R, Duineveld GCA, de Wilde PAWJ (1999) Geographical differences in growth rates of Arctica islandica (Molluska: Bivalvia) from the North Sea and adjacent waters. J Mar Biol Assoc UK 79:907-915

Zielinski S, Pörtner HO (2000) Oxidative stress and antioxidative defense in cephalopods: a function of metabolic rate or age? Comp Biochem Physiol, B 125:147-160

Ziuganov V, Miguel ES, Neves RJ, Longa A, Fernandez C, Amaro R, Beletsky V, Popkovitch E, Kaliuzhin S, Johnson T (2000) Life span variation of the freshwater pearl shell: a model species for testing longevity mechanisms in animals. Ambio 29:102-105 